\title{
Influence of Polysaccharides from Aloe vera (Aloe barbadensis Miller, Liliaceae) on Mechanically Induced Cough in Cats
}

\author{
Martina Šutovská \\ Department of Pharmacology, Jessenius Faculty of Medicine, Comenius University, Martin, Slovakia \\ Received February 4, 2009 \\ Accepted June 30, 2009
}

\begin{abstract}
Different plants have been reported to be a source of polysaccharides that possess a great variety of biological activities, including cough suppression.

The experiments were aimed on the influence of two polysaccharides isolated from the gel (A, HF1-Z) and one from the epidermis (SL-1) of Aloe vera leaves, characterized by chemical composition and structural properties, on the cough reflex.

The method of mechanically induced cough was used in conscious cats. A nylon fibre directed individually into the mucous area of the laryngopharyngeal and tracheobronchial airways via endotracheal cannula elicited the cough reflex.

Statistical evaluation registered cough reflex indicators (number of cough efforts - NE, cough frequency $-\mathrm{NE} \cdot \mathrm{min}^{-1}$ intensity of cough attacks during expiration and inspiration - $\mathrm{IA}^{+}$and IA', intensity of maximal inspiratory and expiratory cough efforts - IME- and $\mathrm{IME}^{+}$) showed that gel polysaccharide HF1-Z possessed higher cough-suppressing activity than dropropizine, a nonnarcotic peripheral cough suppressant. Their antitussive activity was accompanied mainly with a decrease of NE, $\mathrm{IA}^{+}$and $\mathrm{IA}^{-}$from both laryngopharyngeal and tracheobronchial mucous areas of the airways. Results of the presented study also showed minimal influence of polysaccharide HF1-Z on expectoration predictor, IME ${ }^{-}$and $\mathrm{IME}^{+}$.

New pharmacodynamic property of polysaccharides isolated from Aloe vera was shown during experiments, which could be a base of their possible therapeutic use in this indication in future.
\end{abstract}

Cough, antitussive activity, Aloe vera, polysaccharides, codeine, conscious cats

Cough is an important defence mechanism that accelerates mucus clearance, excessive secretions and foreign material from the airways as well as a common symptom of many respiratory and non-respiratory disorders. When cough exceeds its physiological cleaning function, it is necessary to suppress it or maintain it at a tolerable grade (Mazzone et al. 2003). Pharmacological modulation of pathological cough is still unsatisfactory despite intensive research resulting in a large number of publications on experimental results. Opioid antitussives are still widely used in the treatment of dry cough during catarrhs of the respiratory system. Despite their excellent antitussive efficacy, they are associated with a relatively high rate of generally known side effects (Belvisi 2003). In our previous experiments we tested various plant extracts with a typically high polysaccharide content for their antitussive activity (Althaea officinalis L., Malva mauritiana, Rudbeckia fulgida, Mahonia aquifolium, Emblica officinalis and others) and showed cough suppressive potency transcending the efficacy of peripheral antitussives (Nosál'ová et al. 1992; 1993; 1994; 2003). Aloe vera has long been associated with herbal medicine. The leaf gel contains more than 200 different biologically active compounds, e.g. polysaccharides, anthraquinone C-glycosides, anthraquinones, anthrones and various lectins. Polysaccharide acetylated mannans and polymannans have been studied the most, and their various characteristics have already been reported, such as the antibacterial and immunostimulant ones (King et al. 1995; Ferro et al. 2003), yet there is no valid information on their antitussive activity. The structural similarity of the individual polysaccharide constituents isolated from $A$. vera

Address for correspondence:

MUDr. Martina Šutovská, PhD.

Center of Experimental and Clinical Respirology

Department of Pharmacology JFMCU

Sklabinská Street 26

SK-037 53 Martin

Slovakia

Tel.: +421434132535

Fax: +421434134807

E-mail: sutovska@jfmed.uniba.sk

http://www.vfu.cz/acta-vet/actavet.htm 
with carbohydrate agents of a verified property to reduce cough, and the increased number of commercial products containing $A$. vera extract or its purified components recommended for oral application encouraged to continue this research and widen the spectrum of natural remedies able to substitute synthetic drugs.

The aim of the present study was to evaluate the antitussive activity of polysaccharides isolated from different parts of $A$. vera in conscious cats using the method of mechanically induced cough, and to compare it with the efficacy of other known antitussives.

\section{Materials and Methods}

\section{Plant material}

The Aloe vera (Aloe barbadensis Miller, Liliaceae) leaves were harvested in the year 2001 on the plantation of Tambon WangNamKiew, Kumpanseng Nakon Prathon Province, Thailand, belonging to Bangkok Aloe Ltd. 23/1 Mooy workshop producing Aloe vera beverages.

Isolation of polysaccharides from Aloe vera leaves

Fresh $A$. vera leaves were washed with water and sliced to separate the epidermis from the mucilaginous compact gel, which was easily homogenizable in a mixer, giving a moderately viscous liquid. The liquid was filtered through a nylon cloth and the fibrous residue was discarded. The filtrate was precipitated by 1.5 vol isopropyl alcohol (IPA); the fibrous precipitate was filtered, washed with IPA and air-dried. Purification of the product by reprecipitation under the same conditions gave the grayish polysaccharide HF1-Z. When the filtrate was directly treated with 3 vol IPA, short fibres precipitated together with flakes which on air-drying gave the grayish product $\mathrm{A}$.

The skin was cut, homogenized in a mixer with water $(1: 1 \mathrm{v} / \mathrm{v})$, filtered through a nylon cloth and the filtrate was precipitated with 3 vol IPA. The precipitate was washed with IPA and air-dried, giving a yellowish product SL-1.

Animals

Conscious clinically healthy adult cats of both sexes weighing $2000-4000 \mathrm{~g}$ were used in the experiments. Antitussive activity of each carbohydrate component as well as both classic antitussives (dropropizine and codeine) was tested on individual groups of experimental animals. There were 8 to 10 cats in each group, total number of 42. Except for endotracheal cannula implantation, anaesthetics were not used in order to eliminate their possible effect on the cough reflex.

The studies on animals were carried out in accordance with the revised Declaration of Helsinki from 1983 and with the approval of the Ethics Committee of the Jessenius School of Medicine, Comenius University (Slovakia).

\section{Antitussive activity assay}

The experimental procedure was described in detail by Korpáš and Nosál'ová (1991) and Nosál'ová et al. (1989). Briefly, the cough reflex was induced by mechanical stimulation of both laryngopharyngeal and tracheobronchial parts of airways mucosa by a nylon fibre of $0.35 \mathrm{~mm}$ diameter through a surgically implanted chronical endotracheal cannula. This step of experimental procedure was conducted after several days of quarantine, under general anaesthesia induced using thiopental (at the dose of $40 \mathrm{mg} \cdot \mathrm{kg}^{-1} \mathrm{~b} . \mathrm{w}$.) administered intraperitoneally. Standard surgical care aimed at appropriate operative wounds healing followed during the next seven days.

The cough reflex was evoked with a nylon fibre $0.35 \mathrm{~mm}$ in diameter by five consecutive mechanical irritations of laryngopharyngeal $(\mathrm{LPh})$ and tracheobronchial (TB) mucous areas of the airways in experimental animals. The cough-related indicators were reviewed from intraluminal pressure changes recorded on a Biograph 12-03

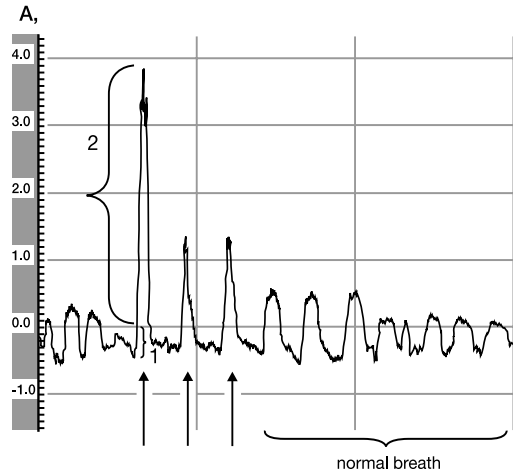

B,

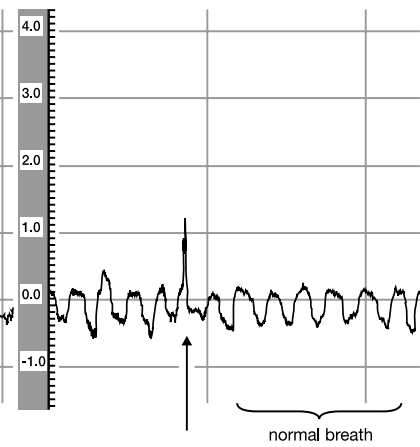

Fig. 1. The record of mechanically induced cough reflex in the conscious cat before administration of HF1-Z (A) and $2 \mathrm{~h}$ after (B). The cough efforts are marked by arrows. A cough effort is represented by a short initial inspiratory phase (1) followed by expulsive expiratory phase (2). The expiratory phase of cough effort in part A of figure is value of $\mathrm{IME}^{+}$ simultaneously. 
electromanometer (Fig. 1). We evaluated the number of cough efforts (NE), cough frequency (NE·min $\left.{ }^{-1}\right)$, intensity of maximal cough effort and intensity of cough attacks during expiration (IME $\mathrm{IA}^{+}$) and inspiration (IME- $\mathrm{IA}^{-}$).

Prior to administration of the tested substance, the induced-cough indicators were recorded as control values for each animal (C). The same indicators were registered after administration of the agent at $0.5,1,2$ and $5 \mathrm{~h}$ intervals. The quantitative characteristic of the cough suppressive effect is expressed (in percentage) as antitussive activity.

The $A$. vera polysaccharides were dissolved in water for injection (Biotika, Slovakia) and given orally (p.o.) at the dose of $50 \mathrm{mg} \cdot \mathrm{kg}^{-1}$. This dose was selected according to previous experience from antitussive tests with other plant extracts (Nosál'ová et al. 2003; 2006).

Antitussive activity of the plant constituents was compared with that of the opiate agonist codeine administered at the dose of $10 \mathrm{mg} \cdot \mathrm{kg}^{-1} \mathrm{p}$.o. and with the cough suppressive effect of peripherally acting dropropizine (50 mg $\cdot \mathrm{kg}^{-1}$ p.o.). Comparative tests with classic drugs were performed under the same conditions.

LPh marked columns on figures represent the values of cough indicators from irritation of the laryngopharyngeal mucous area and TB marked columns from stimulation of the tracheobronchial airway area. The range represents the standard error of mean ( \pm S.E.M.).

Statistical analysis

The data obtained during the experiments were evaluated using the range test of Wilcoxon and Wilcox (1964). The results are presented as mean \pm standard error of the mean (S.E.M.). Asterisks mark significant results. The probability level of 0.05 and higher was considered as significant.

\section{Results}

Characteristic data of polysaccharides isolated from $A$. vera leaves are presented in Table 1. Polysaccharides HF1-Z and A, obtained from the gel of the leaves, are similar in sugar composition, i. e. high proportion of the mannose component (80 and $83 \%$, respectively) and low proportions of glucose and galactose. The total content of polysaccharides in HF $1-\mathrm{Z}$ was $\sim 68 \%$ and in $\mathrm{A} \sim 62 \%$. The polysaccharide isolated from the epidermis (SL-1) is rich in glucose $(64 \%)$, while the proportion of mannose is only $31 \%$. Its total carbohydrate content was $64 \%$. All products contained also protein (10-14\%) and noncombustible residue (17-28\%).

Table 1. Characteristic data of polysaccharides from the leaves of Aloe barbadensis Miller

\begin{tabular}{|l|c|c|c|}
\hline \multirow{2}{*}{ Characteristics } & \multicolumn{3}{|c|}{ Polysaccharides } \\
\cline { 2 - 4 } & HF1-Z & A & SL-1 \\
\hline${ }^{a}$ Yield (\%) & 0.05 & 0.10 & 20.50 \\
\hline Ash (\%) & 17.55 & 27.96 & 13.05 \\
\hline${ }^{b}$ Protein (\%) & 14.37 & 10.00 & 66.47 \\
\hline Total carbohydrate (\%) & 68.08 & 62.04 & SL-1 \\
\hline Sugar composition (mol \%) & HF1-Z & A & - \\
\hline Fucose & - & 4.0 & - \\
\hline Arabinose & 1.6 & - & 31.6 \\
\hline Xylose & 79.5 & 83.6 & 64.0 \\
\hline Mannose & 11.8 & 2.4 & 2.8 \\
\hline Glucose & 7.1 & 4.7 & \\
\hline Galactose & & & \\
\hline
\end{tabular}

a'Yields per fresh leaves

${ }^{\mathrm{b}}$ Obtained by multiplying the nitrogen content by the coefficient 6.25

The results of experiments with polysaccharide agents isolated from $A$. vera showed according to the statistical analysis of the antitussive activity indicators $\left(\mathrm{NE}, \mathrm{IA}^{+}\right.$and IA $^{-}$), a mild cough suppressive effect of gel agent A (above 23\%) lower than both peripheral and centrally acting antitussives and epidermal polysaccharide SL-1 (above $30 \%$ ) comparable to the cough suppression of dropropizine. Orally administered polysaccharide HF1-Z resulted in significant antitussive activity (almost 40\%), which exceeded the efficacy of a peripheral antitussive agent but it was still lower than that of 


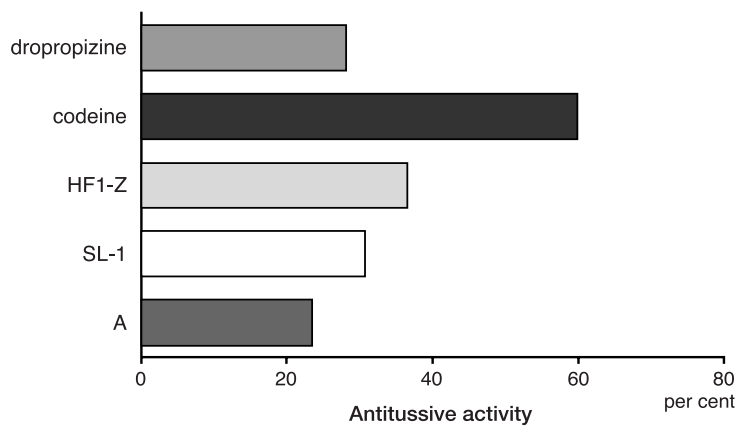

Fig. 2. Comparison of the antitussive activity (\%) of codeine at the dose of $10 \mathrm{mg} \cdot \mathrm{kg}^{-1} \mathrm{~b}$.w., dropropizine at the dose of $50 \mathrm{mg} \cdot \mathrm{kg}^{-1} \mathrm{~b}$.w. and all tested polysaccharides isolated from $A$. vera: gel samples A and HF1-Z and epidermal polysaccharide SL-1. All agents were given orally at the dose of $50 \mathrm{mg} \cdot \mathrm{kg}^{-1} \mathrm{~b}$.w. to conscious cats. the classical narcotic antitussive drug - codeine (Fig. 2). The analysis of obtained data showed that agent A evoked only isolated significant decline of cough reflex indicators. The evaluated values of mechanically induced cough reflex after sample SL-1 administration indicated its more eminent influence on LPh mucous area of the airways. Unlike agent HF1-Z, the individual indicators recorded on SL-1 application were not decreased in any corresponding and continual manner (Table 2).

Administration of the polysaccharide HF1-Z brought about a significant decrease in the number of cough efforts (NE) and intensity of cough attacks $\mathrm{IA}^{+}$and $\mathrm{IA}^{-}$(Fig. 3 and 4), except for the intensity values of cough attack during inspiration (IA') from the laryngopharyngeal area $(\mathrm{LPh})$.

Table 2. The changes of all main predictors of antitussive activity before (C) and after all tested Aloe vera originated polysaccharides (A, SL-1. HF1-Z) administration in 0.5, 1, 2 and $5 \mathrm{~h}$ time intervals

(expressed as mean \pm S.E.M.). Significance (evaluated by Wilcoxon-Wilcox test) marked by asterisks

\begin{tabular}{|c|c|c|c|c|c|c|c|c|c|c|c|c|c|c|c|c|}
\hline \multirow[b]{2}{*}{ agent } & \multirow[b]{2}{*}{$\mathrm{AM}$} & \multicolumn{5}{|c|}{$\begin{array}{l}\text { Number of cough efforts } \\
\text { (NE) }\end{array}$} & \multicolumn{5}{|c|}{$\begin{array}{c}\text { Intensity of the cough attack, } \\
\text { inspirium (IA })\end{array}$} & \multicolumn{5}{|c|}{$\begin{array}{c}\text { Intensity of the cough attack, } \\
\text { expirium }\left(\mathrm{IA}^{+}\right)\end{array}$} \\
\hline & & $\mathrm{C}$ & 0.5 & 1 & 2 & 5 & $\mathrm{C}$ & 0.5 & 1 & 2 & 5 & $\mathrm{C}$ & 0.5 & 1 & 2 & 5 \\
\hline \multirow{6}{*}{ A } & \multirow{3}{*}{$\mathrm{LPh}$} & 4 & 2.8 & 3 & 4.2 & 3.6 & 1 & 0.72 & 1.02 & 1.08 & 0.8 & 3.52 & 2.18 & 1.92 & 2.56 & 1.86 \\
\hline & & \pm & \pm & \pm & \pm & \pm & \pm & \pm & \pm & \pm & \pm & \pm & \pm & \pm & \pm & \pm \\
\hline & & 0.82 & 0.67 & 0.29 & 0.78 & 0.46 & 0.36 & 0.2 & 0.36 & 0.4 & 0.16 & 0.79 & 0.38 & 0.26 & 0.87 & 0.77 \\
\hline & \multirow[b]{3}{*}{$\mathrm{TB}$} & & & & & & & & & & & & & & & \\
\hline & & 4.4 & 3 & 3.4 & 2.8 & 3 & 0.88 & 1 & 0.7 & 0.4 & 0.5 & 3.46 & 2.62 & 2.62 & 2.78 & 1.74 \\
\hline & & 0.62 & $\begin{array}{c}0.29 \\
*\end{array}$ & 1.14 & 0.53 & 0.29 & 0.25 & 0.34 & 0.4 & $\begin{array}{c}0.18 \\
*\end{array}$ & 0.23 & 1.37 & 1.44 & 1.64 & 1.84 & 0.89 \\
\hline \multirow{7}{*}{ SL-1 } & \multirow{4}{*}{$\mathrm{LPh}$} & 5.1 & 3.6 & 4.3 & 3.3 & 3.4 & 1.7 & 1.4 & 1.73 & 1.07 & 0.9 & 3.65 & 2.26 & 2.34 & 1.32 & 2.42 \\
\hline & & \pm & \pm & \pm & \pm & \pm & \pm & \pm & \pm & \pm & \pm & \pm & \pm & \pm & \pm & \pm \\
\hline & & 0.49 & 0.48 & 0.57 & 0.32 & 0.45 & 0.44 & 0.44 & 0.38 & 0.28 & 0.22 & 0.95 & 0.59 & 0.44 & 0.32 & 0.46 \\
\hline & & & $*$ & & $*$ & $*$ & & & & $*$ & $*$ & & $*$ & & $*$ & \\
\hline & \multirow{3}{*}{ TB } & 5.9 & 4.3 & 4.5 & 3.7 & 3.4 & 1.63 & 1.63 & 1.32 & 1.37 & 0.62 & 4.68 & 4.08 & 2.69 & 2.37 & 3.19 \\
\hline & & \pm & \pm & \pm & \pm & \pm & \pm & \pm & \pm & \pm & \pm & \pm & \pm & \pm & \pm & \pm \\
\hline & & 0.96 & 0.83 & 0.74 & $\begin{array}{c}0.57 \\
*\end{array}$ & $\begin{array}{c}0.53 \\
* *\end{array}$ & 0.42 & 0.8 & 0.58 & 0.52 & $\begin{array}{c}0.24 \\
* *\end{array}$ & 1.49 & 1.24 & 0.62 & 0.68 & 0.67 \\
\hline \multirow{8}{*}{ HF1-Z } & \multirow{4}{*}{$\mathrm{LPh}$} & 4.4 & 4 & 2.8 & 2.5 & 2.7 & 0.59 & 0.78 & 0.48 & 0.51 & 0.6 & 4.2 & 4.87 & 3.31 & 2.35 & 1.82 \\
\hline & & \pm & \pm & \pm & \pm & \pm & \pm & \pm & \pm & \pm & \pm & \pm & \pm & \pm & \pm & \pm \\
\hline & & 0.87 & 0.82 & 0.49 & 0.34 & 0.3 & 0.15 & 0.23 & 0.18 & 0.12 & 0.21 & 1.0 & 1.48 & 0.58 & 0.41 & 0.26 \\
\hline & & & & $* *$ & $* *$ & * & & & & & & & & $*$ & $*$ & $* *$ \\
\hline & \multirow{4}{*}{$\mathrm{TB}$} & 5.9 & 3.6 & 3.1 & 2.5 & 2.2 & 1.1 & 0.37 & 0.54 & 0.73 & 0.41 & 6.81 & 4.09 & 3.41 & 2.57 & 1.9 \\
\hline & & \pm & \pm & \pm & \pm & \pm & \pm & \pm & \pm & \pm & \pm & \pm & \pm & \pm & \pm & \pm \\
\hline & & 0.9 & 0.54 & 0.38 & 0.27 & 0.3 & 0.23 & 0.14 & 0.18 & 0.17 & 0.17 & 2.16 & 0.44 & 0.61 & 0.41 & 0.31 \\
\hline & & & $* *$ & $*$ & $* *$ & $* *$ & & $*$ & & & $*$ & & $*$ & $*$ & $* *$ & $* *$ \\
\hline
\end{tabular}

AM- airways mucosa LPh- laryngopharyngeal, TB- tracheobronchial $* p<0.05 ; * * p<0.01$ 
By the mechanical provocation of cough the author observed significant reduction of $\mathrm{NE}$ in tracheobronchial mucous area (TB) area $0.5(p<0.01), 1 \mathrm{~h}(p<0.05), 2$ and $5 \mathrm{~h}$ $(p<0.01)$ after the administration of HF1-Z at the dose of $50 \mathrm{mg} \cdot \mathrm{kg}^{-1}$ body weight (b.w.) orally (Fig. 3). Similarly, significant reduction of $\mathrm{IA}^{+}$in tracheobronchial TB 0.5 and 1

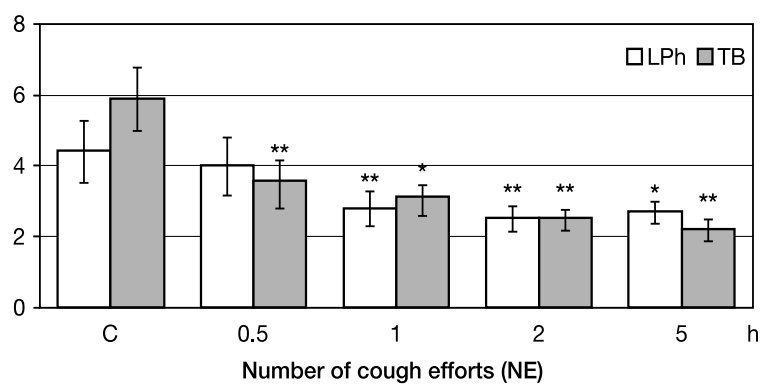

Fig. 3. Number of cough efforts (NE) recorded in control (C labelled column represents the value before administration of tested substance) and $0.5,1,2$ and $5 \mathrm{~h}$ after administration of $50 \mathrm{mg} \cdot \mathrm{kg}^{-1} \mathrm{~b} . \mathrm{w}$. of gel polysaccharide HF1-Z of $A$. vera p.o. LPh columns represent mean values of cough indicator from laryngopharyngeal area stimulation; TB columns represent mean values of cough indicator of tracheobronchial area stimulation. The range means the standard error of the mean ( \pm S.E.M.). Asterisks represent significance according to Wilcoxon-Wilcox test $(* p<0.05, * * p<0.01)$.
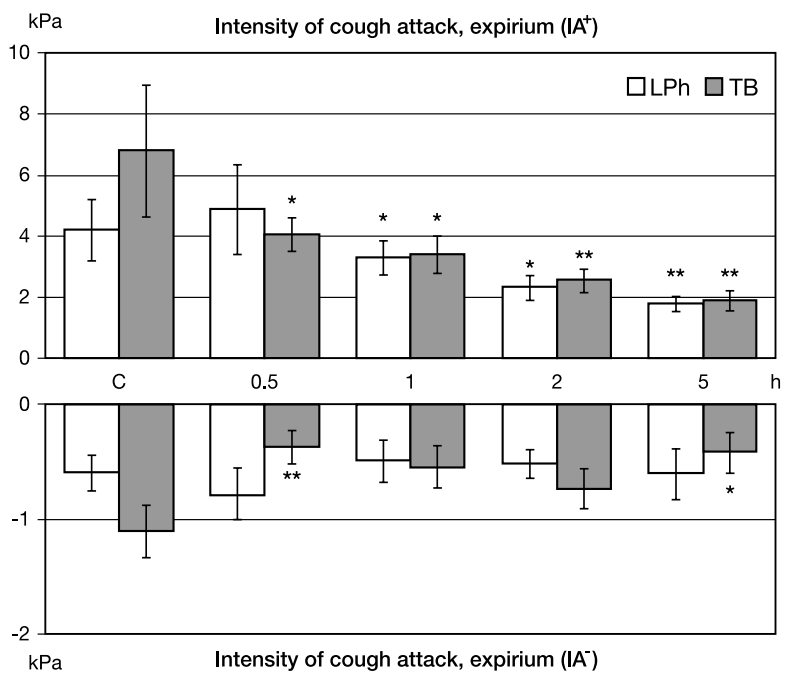

Fig. 4. Intensity of cough attack during expirium $\left(\mathrm{IA}^{+}\right)$and during inspirium (IA-) after the administration of $50 \mathrm{mg} \cdot \mathrm{kg}^{-1} \mathrm{~b}$.w. of HF1-Z polysaccharide sample p.o. (For explanations see also Fig. 2.) of intensity of maximal expiratory and inspiratory cough efforts (IME- by almost $80 \%$ and $\mathrm{IME}^{+}$by more than $67 \%$ ), which are the main predictors of expectoration ability. On the contrary, cough suppression induced by HF1-Z is reflected mainly in changes of the number of cough efforts (NE) and intensity of expiratory cough attacks $\left(\mathrm{IA}^{+}\right)$, whereas IME- was lowered by $19 \%$ and $\mathrm{IME}^{+}$was reduced only by $9 \%$ approximately. $\mathrm{h}(p<0.05)$, and 2 and $5 \mathrm{~h}(p<$ $0.01)$ after administration of this substance was observed (Fig. 4). A quick onset of the effect recorded after irritation of TB is indicated by the first significant drop of both indicators $0.5 \mathrm{~h}$ after administration of the polysaccharide. However, significant reduction of intensity of cough attacks during inspiration (IA-) from TB area was observed only $0.5(p<0.01)$ and $5 \mathrm{~h}(p<$ 0.05 ) after administration of the agent.

The graphical presentation (Fig. 3) distinctly shows that a decrease of NE from the laryngopharyngeal area $(\mathrm{LPh})$ was registered later, $1 \mathrm{~h}(p<$ 0.01 ) after administration of the tested substance and continued at the subsequent measured time intervals after $2 \mathrm{~h}(p<0.01)$ and $5 \mathrm{~h}(p<0.05)$. Stimulation of the $\mathrm{LPh}$ area caused a similar belated decrease of $\mathrm{IA}^{+}$ compared to the indicators of mechanically induced cough from TB significant in the measurements taken $1 \mathrm{~h}, 2 \mathrm{~h}(p$ $<0.05)$ and $5 \mathrm{~h}(p<0.01)$ after administration of the HF1-Z substance (Fig. 4).

Comparison of all antitussive activity indicators of HF1-Z with those of codeine showed that the remarkable reduction of mechanically induced cough brought about by codeine administration is accompanied also by an expressive decrease 


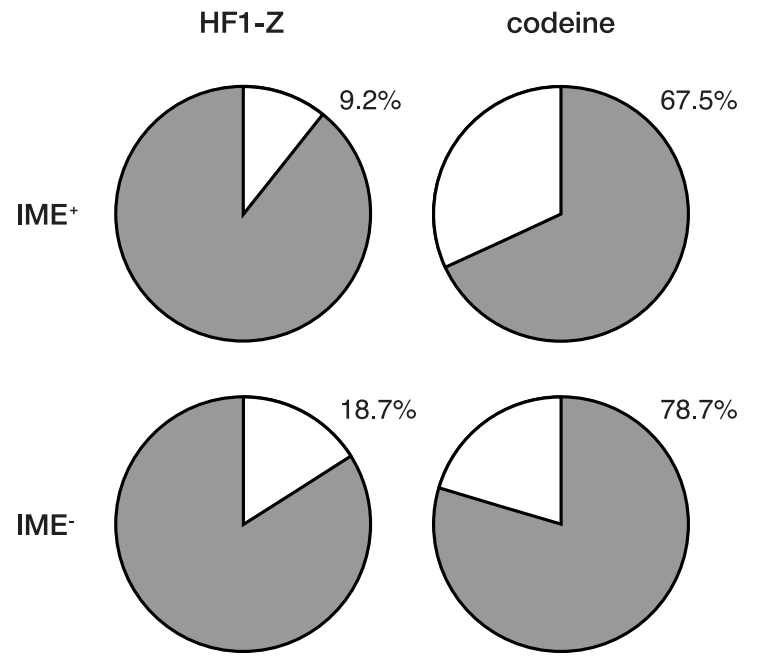

Fig. 5. Influence of $50 \mathrm{mg} \cdot \mathrm{kg}^{-1} \mathrm{~b}$.w. of HF1-Z p.o. and codeine (dose of $10 \mathrm{mg} \cdot \mathrm{kg}^{-1}$ b.w.) on intensity of maximal cough effort in inspirium (IME-) and intensity of maximal cough effort in expirium $\left(\mathrm{IME}^{+}\right)$. The decrease of both indicators as important predictors of expectoration intensity is represented by the dark part of graphs. has been linked with improved blood glucose levels in diabetes and with lower blood lipids in hyperlipidaemia (Yongchaiyudha et al. 1996). In other diseases, preliminary studies have suggested oral $A$. vera gel may reduce symptoms and inflammation of ulcerative colitis (Langmead et al. 2004). Compounds extracted from A. vera have been used as an immunostimulant that aids in fighting cancer in cats and dogs (King et al. 1995). A. vera extracts have antibacterial, anti-inflammatory, antiviral and antifungal activities (Tian et al. 2003; Hu et al. 2003). A. vera was shown to inhibit the growth of Streptococcus and Shigella species in vitro (Ferro et al. 2004).

It is generally known that anti-inflammatory properties of various substances could be associated with cough suppression (Korpáš and Nosál'ová 1991). Based on this fact and lack of references on the antitussive activity of $A$. vera polysaccharides in literature, we decided to assess the effect of this plant that could be potentially used in therapy of pathological cough.

The antitussive effect of various plant extracts was tested on mice and rats and the cough reflex was provoked by citric acid aerosol, capsaicin or sulphur dioxide (Lin et al. 2008; Mazumder et al. 2007). The method of mechanical stimulation of airways of both laryngopharyngeal and tracheobronchial mucous areas was preferred in the cats. It is considered a point stimulatory method with constant provocation intensity; the possibility of cough receptor adaptation is very low and it simulates the natural conditions of the onset of the cough reflex. Furthermore, it represents an objective method appropriate for registration and evaluation of more qualitative and quantitative determinants of the cough reflex (Nosál'ová et al. 1989). During experiments, conscious cats were used as suitable animal model to eliminate a possible negative impact of anaesthetics on the structures of the cough reflex arc.

The results of the presented experiments with herbal polysaccharides isolated from $A$. vera showed high cough suppressive ability of the purified $A$. vera gel polysaccharide HF1-Z connected mainly with an influence on the number of cough efforts (NE) and 
intensity of cough attacks during expiration and inspiration $\left(\mathrm{IA}^{+}, \mathrm{IA}^{-}\right)$. These variables of mechanically induced cough are the most important predictors of the antitussive activity of any substance. Comparison with classical antitussive drugs, both narcotic and non-narcotic, revealed that reduction of cough indicators by herbal constituents is lower than reduction by codeine, but significantly higher than or similar to that of the peripherally acting antitussive dropropizine. Codeine is used as a reference drug for antitussive activity tests because of the excellent cough suppressing activity $(62 \%)$ at the dose of $10 \mathrm{mg} \cdot \mathrm{kg}^{-1}$ b.w. orally. Side effects that could limit its use, e.g. depression of the respiratory centre, decreased mucus secretion in bronchioles, inhibition of ciliary activity as well as increase of sputum viscosity are well known (Rang et al. 1999). One of them, the decrease of expectoration, is accompanied with reduction of the intensity of the maximal expiratory and inspiratory cough efforts (IME- and $\mathrm{IME}^{+}$). These variables were lowered by $74 \%$ when codeine was administered in our experimental studies. Guaifenesin is regarded as expectoration promoting cough suppressant (Dicpinigaitis and Gayle 2003). This drug reduced IME- and $\mathrm{IME}^{+}$value in experiments only by $15 \%$. The HF $1-Z$ polysaccharide sample in antitussive activity tests did not inhibit the intensity of maximal cough efforts in inspiration and expiration $\left(\mathrm{IME}^{-}\right.$and $\mathrm{IME}^{+}$) significantly, and decreased the total value of expectoration indicators only by $14 \%$. These findings indicate that the tested herbal polysaccharide suppressed the cough reflex but not expectoration and could be useful for both productive and nonproductive cough treatment.

The onset of the effect of HF1-Z carbohydrate was very prompt and the tracheobronchial airways area was influenced earlier than the laryngopharyngeal part. Significant suppression of cough from TB was observed after $0.5 \mathrm{~h}$, whereas cough from LPh was attenuated after $1 \mathrm{~h}$. Cough remained depressed during the whole time of the experiment.

Mechanisms of the antitussive action of plant polysaccharides, including the carbohydrates isolated from $A$. vera, are still not clarified. Considering the pharmacokinetic indicators of herbal polysaccharides, e.g. low gastrointestinal absorption, it is highly probable that their antitussive effect is connected with the peripheral or reflexive mechanism of action. The mentioned polysaccharide HF1-Z influence on NE, $\mathrm{IA}^{-}$and $\mathrm{IA}^{+}$confirmed the peripheral mechanism of cough suppression. According to previous findings of Korpás and Nosál'ová (1991), the compounds with dominant peripheral mechanisms reduce the frequency of coughing and have much less influence on its amplitude during expiration. The frequency of coughing depends probably on the condition of the cough receptors, whereas the amplitude is determined by the condition of the cough centre. Generally it is accepted that the cough suppressive effect of polysaccharides may be explained by their protective effect on cough receptors. Orally administered and swallowed polysaccharides increase mucus and saliva production and thus protect and cover cough receptors in the airways and other respiratory and extra-respiratory anatomical structures responsible for the onset of cough even if they don not reach the airways. The volume of mucus could be induced reflexively through direct contact with epipharyngeal or gastric mucosa nerve terminals. Some cough influencing agents similar to polysaccharides, which are not absorbed, e.g. saponins, interact with gastrointestinal vagal nerves contributing to the regulation of mucous gland production in the airways (Preuss et al. 2007). According to Irwin and Madison (2000), irritated epipharyngeal group of neurons during acute rhinosinusitis results in pathological cough; intranasally given antihistamines and corticosteroids reduce coughing. The cough reflex is very close to bronchoconstriction. Therefore, bronchodilation using another peripheral site of the cough reflex arc might (in theory) also participate in the antitussive activity of polysaccharides. Involvement of certain peripheral cough reflex arc structures in the mechanism of cough suppression induced by plant polysaccharides in guinea pigs was reported, from the character of the conducted experiments we may only 
speculate about the possible details of the antitussive activity of $A$. vera carbohydrates (Sutovská et al. 2009).

In conclusion, we can summarize that a certain fraction of polysaccharides of Aloe vera leave gel labelled as HF1-Z possess significantly higher antitussive activity than dropropizine that represents the group of peripherally acting non-narcotic antitussives.

\section{Vplyv polysacharidov z Aloe vera (Aloe barbadensis Miller, Liliaceae) na kašl'ový reflex vyvolaný mechanickým stimulom u mačiek}

Viaceré vedecké práce informujú, že niektoré rastliny sú zdrojom polysacharidov so širokou škálou biologických účinkov, vrátane útlmu kašl’a.

Ciel'om prezentovaných experimentov bolo overenie vplyvu dvoch polysacharidov (A, HF1-Z) pochádzajúcich z gélu listov Aloe vera (Aloe barbadensis Miller, Liliaceae) a jedného izolovaného z epidermy listov rastliny (SL-1) so špecifikovanými chemickými a štrukturálnymi vlastnost’ami na kašlový reflex.

Použili sme metodiku mechanicky indukovaného kašl'ového reflexu u bdelých mačiek. Kašl'ový reflex sme vyvolávali pomocou nylonového vlákna, ktoré bolo izolovane zavedené cez endotracheálnu kanylu do laryngofaryngeálnej a tracheobronchiálnej slizničnej oblasti dýchacích ciest.

Štatistickým vyhodnotením zaznamenávaných parametrov mechanicky indukovaného kašl'a (počet nárazov kašl'a - NE, frekvencia kašl'a - NE·min ${ }^{-1}$ sila ataku kašl'a v expíriu a inspíriu - $\mathrm{IA}^{+}$a $\mathrm{IA}^{-}$, intenzita maximálneho exspiračného a inspiračného nárazu kašla - IME- a IME ${ }^{+}$) sme zistili, že polysacharid HF1-Z z gélu listov rastliny má kašel' supresívny účinok prevyšujúci schopnost' dropropizínu, nenarkotického periférneho liečiva používaného na útlm kašl'a. Antitusický efekt polysacharidu bol spojený predovšetkým s poklesom NE, $\mathrm{IA}^{+}$a $\mathrm{IA}^{-} \mathrm{z}$ laryngofaryngeálnej a tracheobronchiálnej slizničnej oblasti dýchacích ciest. Výsledky experimentov s polysacharidom HF1-Z tiež poukázali na minimálne ovplyvnenie expektorácie, ktorej dôležitým indikátorom sú ukazovatele IMEa IME $\mathrm{IM}^{+}$.

Naše experimenty odhalili novú farmakodynamickú vlastnost' polysacharidov z Aloe vera a vytvorili tak základ pre ich možné budúce terapeutické využitie v tejto indikácii .

\section{Acknowledgements}

I would like to acknowledge preparation of polysaccharide samples used in experiments to Alžbeta Kardošová, $\mathrm{PhD}$, retired researcher of Institute of Chemistry, Slovak Academy of Sciences, Bratislava.

The work was supported by the project "Center of Experimental and Clinical Respirology" co-financed from EC sources as well as by the grant APVV-0030-07.

\section{References}

Belvisi MG 2003: Airway sensory innervation as a target for novel therapies: an outdated concept? Curr Opin Pharmacol 3: 239-243

Dicpinigaitis PV, Gayle YE 2003: Effect of guaifenesin on cough reflex sensitivity. Chest 124: 2178 - 2181

Ferro VA, Bradbury F, Cameron P, Shakir E, Rahman SR, Stimson WH 2003: In Vitro Susceptibilities of Shigella flexneri and Streptococcus pyogenes to Inner Gel of Aloe barbadensis Miller. Antimicrob Agents Chemother 47: 1137-1138

$\mathrm{Hu} \mathrm{Y}, \mathrm{Xu} \mathrm{J}, \mathrm{Hu} \mathrm{Q}$ 2003: Evaluation of antioxidant potential of aloe vera (Aloe barbad. Miller) extracts. J Agric Food Chem 51: 7788-7791

Irwin SR, Madison MJ 2000: The Diagnosis and Treatment of Cough. The New England Journal of Medicine 343: 1715-1721

King GK, Yates KM, Greenlee PG, Pierce KR, Ford CR, McAnalley BH, Tizard IR 1995: The effect of Acemannan Immunostimulant in combination with surgery and radiation therapy on spontaneous canine and feline fibrosarcomas. J Am Anim Hosp Assoc 31: 439-447

Korpáš J, Nosál'ová G 1991: Pharmacotherapy of cough. Martin, Osveta, p. 335

Langmead L, Feakins RM, Goldthorpe S 2004: Randomized, double-blind, placebo-controlled trial of oral aloe vera gel for active ulcerative colitis. Alimentary Pharmacology \& Therapeutics 19: 739-747 
Lin LG, Li KM, Tang CP, Ke CQ, Rudd JA, Lin G, Ye Y 2008: Antitussive stemoninine alkaloids from the roots of Stemona tuberosa. J Nat Prod 71: 1107-1110

Mazumder A, Bhattacharya S, Mazumder R 2007: In vivo antitussive potentiality of Lagerstroemia parviflora flower extract using a cough model induced by sulfur dioxide in mice. Nat Prod Res 21: 217-220

Mazzone SB, Canning BJ, Widdicombe JG 2003: Sensory pathways for the cough reflex. In: Chung F, Widdicombe JG, Boushey HA (Eds): Cough: Causes, Mechanisms and Therapy. Blackwell Publishing, Oxford, pp. 161-172

Nosál'ová G, Capek P, Kardošová A, Strapková A 1994: Changes in cough reflex induced by administration of polysaccharides from flowers of Malva mauritiana L. Pharm Pharmacol Lett 3: 245-248

Nosalova G, Capek P, Sutovska M, Franova S, Matulova M 2006: Antitussive Active Polysaccharides from Ornamental - Medicinal Plants. Floriculture, Ornamental and Plant Biotechnology IV: 471-480

Nosál'ová G, Mokrý J, Khan MTH 2003: Antitussive activity of the fruit extract of Emblica officinalis Gaertn. (Euphorbiaceae). Phytomedicine 10: 583-589

Nosál'ová G, Strapková A, Kardošová A, Capek P 1993: Antitussive activity of a rhamnogalacturonan isolated from the roots of Althaea officinalis L., var. Robusta. J Carbohydrate Chemistry 12: 589- 596

Nosál'ová G, Strapková A, Kardošová A, Capek P, Zathurecký L, Bukovská E 1992: Antitussive action of extracts and polysaccharides of marshmallow (Althaea officinalis L., var. Robusta). Pharmazie 47: 224- 226

Nosál'ová G, Strapková A, Korpáš J, Criscuolo D 1989: Objective assessment of cough suppressants under normal and pathological experimental conditions. Drugs Exptl Clin Res XV: 77-81

Preuss HG, Echard B, Bagchi D, Stohs S 2007: Inhibition by natural dietary substances of gastrointestinal absorption of starch and sucrose in rats and pigs: 1. Acute studies. Int J Med Sci 4: 196-202

Rang HP, Dale MM, Ritter JM 1999: Pharmacology $4^{\text {th }}$ ed. Edinburgh, London, New York, Philadelphia, Sydney, Toronto, Churchill Livingstone, p. 830

Sutovská M, Nosálová G, Sutovský J, Franová S, Prisenznáková L, Capek P 2009: Possible mechanisms of dosedependent cough suppressive effect of Althaea officinalis rhamnogalacturonan in guinea pigs test system. Int J Biol Macromol 45: 27-32

Tian B, Hua YJ, Ma XQ, Wang GL 2003: Relationship between antibacterial activity of aloe and its anthraquinone compounds. Zhongguo Zhong Yao Za Zhi 28: 1034-1037

Vogler BK, Ernst E 1999: Aloe vera: a systematic review of its clinical effectiveness. Br J Gen Pract 49: $823-828$

Wilcoxon F, Wilcox RA 1964: Some rapid approximate statistical procedures. Lederle, Division of American Cyanamid Co., New York

Yongchaiyudha S, Rungpitarangsi V, Bunyapraphatsara N, Chokechaijaroenporn O 1996: Antidiabetic activity of Aloe vera L. juice. I. Clinical trial in new cases of diabetes mellitus. Phytomedicine 3: 241-243 
